\title{
Citizen Involvement: Fostering Alternatives and Risk Considerations on Natuna Rural Coastal Borderland
}

\author{
${ }^{1}$ Armauliza Septiawan, ${ }^{2}$ Sintaningrum \\ ${ }^{12}$ Department of Public Administration \\ University of Padjajaran, Indonesia, $25^{\text {th }}$ Bukit Dago Utara Street, \\ Bandung, Indonesia. \\ Email: ${ }^{1}$ armauliza14001@ gmail.unpad.ac.id, ${ }^{2}$ sintaher@yahoo.com
}

\begin{abstract}
The rural coastal development phenomenon in Natuna Regency hasn't shown improvement significantly, especially in potential development resources utilizing to be a strategy and performance which can reduce the development problems faced. This study aims to explore the suitability of the rural coastal development strategy with its main mission, alternative actions where are the risk considerations and also the citizen involvement on the rural coastal development strategy. This research using a qualitative approach. Hence, the research process is carried out deeply and through the data collection techniques process systematiclythrough of interviewing informants in the field, studying data and relevant information analyzing. The results explain about the Natuna rural coastal development strategy has not fully implemented the risk considerations as a main consequence to thedevelopment benefits failure activities undertaken. This finding is the lack of involvement influence for the rural coastal villagers, especially in the citizen's idea repositioning process as an alternative forrural developing strategy implemented,thus for the development goals achieving in Natuna rural coastal.
\end{abstract}

Keywords: Rural coastal; Development; Strategy; Effectiveness

Link DOI : $\underline{\text { http://dx.doi.org/10.31314/pjia.7.2.101-107.2018 }}$

Copyright @ 2018, Publik : (Jurnal Ilmu Administrasi), ISSN: 2301-573X (Print), ISSN: 25812084 (Online) 


\section{INTRODUCTION}

Indonesia is an archipelagic state and has 16,056 large and small islands whice have been registered to the United Nations form until May 2018. If this counting information is confronted with the of the National Army Hydrology Research Centre Report means 1,444 islands still aren't registered formally. By this archipelagic region characteristics, Republic of Indonesia faces a very difficult challenge, namely maintaining sovereignty in the border state area which is mostly found in the rural characteristics with the archipelago inherently. Various violations of maritime law boundary between this countries are one of the most concerns that always increasingly trending in time. Nowadays the most popular violation action is the illegal fishing in Indonesia's sea border area with the contiguous fisheries countries.

One of the difficulty phenomena in realizing a development process sovereignty in Indonesia can be found in the rural coastal area in the Natuna Regency, which have 154 large and small islands and about 27 islands (17.53\%) already inhabited and the rest 127 islands are uninhabited. With this Natuna Regency character, has a rural coastal area which is located on small islands and separated from the main large island called "Ranai" either. In the distance terms and separate accessibility villages it certainly provides an obstacle to the development activities because until now both of the rural coastal official also the communities in the small islands, are still very hardly dependent to the district government which located on the main big island (Ranai). Whereas based on the current rural coastal development paradigm, the rural coastal where the community and rural coastal official are able to share an important same role in determining the rural coastal development policy direction into an independent and rural sovereignty.

$\begin{array}{lcc}\text { Withal } & \text { overcoming } & \text { these } \\ \text { difficulties challenge, the rural } \\ \text { government } & \text { continuous } & \text { runs }\end{array}$
operationally around a problematic circle which still can't be resolved. Lack of developing citizen economic growth, working costs highly because the need to coordinate and cooperate with other main island parties, rural swelling spends because the goods needed for supporting the public services implementation also expensive, lack of health facilities accessing especially in emergency case and high costs for people who wish to attending higher level formal education at university. The problems which are felt by the citizen being fester continuously up to the complexity problems, hence these requires an appropriate outlined strategy as an effort to achieve the development of Natuna rural coastal in a and sustainable issues comprehensively.

The the rural coastal development in Natuna Regency has been yet showing the renewal significant sign, especially in transforming the potential development resources owned by the village into working strategies and results which are reducing the development problems faced. That's the rural coastal development result portrait in Natuna Regency which also hasn't independence characterized. The rural coastal still has a good reflection dependency from the development capacity for generating 
policies, the public services scope in a broad sense, until operationally it is also reflected in the series of rural development management functions. This statement is evidenced by the rural coastal development parameters achieved also uniformity same as used by nonrural coastal in Natuna and even other villages in Indonesia. Whereas if this look closely at the Natuna rural coastal, the area characteristics are very different from other villages, both in the district or with the other villages in Indonesia. This evidence is illustrated by an assessment results of various documents related to the Natuna rural coastal development, namely the planning documents and rural development performance achieved report which have a close resemblance in comparison with the non-coastal development characterized documents in Natuna.

This problem description motivates this research for taking a part which systematically and deeply think, especially for trying to answer the questions about the citizen involvement on strategy process that enabling the Natuna rural coastal better qualified development strategy. So that Natuna rural coastal development implementation also achievable performance effectively and sustainable either.

The relevant research to the experienced phenomena above has been widely storied. However, the rural coastal development phenomenon where located on the outer islands and border state area is still very rarely carried out. The carried out research mapping results before systematically through refer to the rural
Coastal Development Effectiveness illustrate that, the thinking terminology of that locus as the main subject of rural development not an easy issues. But it requires a variety of considerations, ideas or deeply thoughts that more advanced than rural coastal repositioning. This result actually puts this research in a strategic urgency with the specifically intention of revealing and about the ideas harmonization and behaviors between the citizens and the rural coastal official which includes planning, budgeting, implementation, controlling and evaluation, will further strengthen the rural coastal development practices in border area effectively.

An effective rural coastal development is not the development where has succeeded in achieving all the same objectives and programs with other villages because any different regional characteristics and even different potential natural resources ownership. This thinking analogy is very simple where for a trader, an effective way of trading is a method which able to provide optimal benefits, for students in a school also get a first place in class is an effective sign of learning. This means interpreting the effectiveness of rural coastal development is certainly different from villages around the plantation area (other non-coastal villages). In other words, the rural coastal villages where are the outermost fence of the country, face the problem of isolation in development, require a strategic process to solve a lot of specific problems. Likewise, the research stated above, namely that each research locus has a major concern that is different view in 
looking at the rural development effectiveness.

\section{RESEARCH METHOD}

The entire unit of observation in this study is also numerously hence it includes elements of the rural government, the citizen or community and the entrepreneurs in the village. Thus, operationally, this study certainly requires procedures for determining the right research informants so that the implementation of research can later produce answers according to existing scientific rules and procedures. Thus the selection of procedures for determining research informants purposively on elements of the village government that will explain village development in the perspective of exercising authority as an organization, the community in the perspective of personhood and experience as well as the entrepreneurs in the village is the right choice for the research implementation.

This research is located in the rural coastal area spread in Natuna Regency, Riau Islands Province. This research described previously is a many challenges research due to the extent of the area and the scope of the research discussion technically. Hence I'm expected to require a long time research which is less than one year research year following the Village Budget and Expenditure Plan (APBDes process).

Natuna Regency has a lot of villages that are very specific in location, namely on the outermost small islands which constitute the national borders and total 70 villages. Because the extent of the research location needs to be technically restricted or filtration of the total number of villages. It was decided in the design of this study to use the location in 2 (two) villages namely Tanjung Pala Village in Pulau Laut District which consist more than 1 small island and also the Limau Manis Village which is a rural coastal characteristic area attached to the island. These two villages have fulfilled representation for rural coastal Natuna Regency and considered representatively because this research is not based on the representation of the location population or using location sampling techniques.

Fulfilling the need to find answers to the formulation of the first problem and the second research will be used in the form of interview guidelines for research instruments. The instrument of this research has been tested for validity and through discussion with experts (academics and practitioners) which was carried out in a limited discussion before the actual research was carried out.

Data obtained through the results of field research will be processed first through the use of Triangulation Techniques. Thus research information that refers to the quality of the data will produce conclusions that have meaning.

The data analysis process becomes useful information for in-depth disclosure of the effectiveness of coastal village development in Natuna Regency. This means that there is a tendency to use techniques that are diverse and adapted to the characteristics of data collected from the location of the research.

Data sourced from observations will be compared and filtered based on their relevance to the focus of this 
research. The data obtained in the form of photos and videos are then sorted, reduced, and given a special mark (coding) based on their relevance to the formal or informal interaction process (Creswell, 2013).

Furthermore, the information from the interview results was also analyzed using an analysis model that had been developed by Miles and Huberman (Creswell, 2013) where the results of interviews besides being recorded were also recorded into summary sheets about field notes. Thus it does not rule out the possibility of an analytical process with this technique to be implemented integrally along with the data collection process in the field.

Data collected through relevant documents, literature or reports, after obtaining approval from the authorized parties, will be quoted, guided as important records which are then analyzed simultaneously with the analysis requirements according to the stages. Literature is very useful for the design of this research especially in the effort to put the focus of research on the scientific map and the comparative process of possible results of this research later. While the report will also strengthen the analysis carried out because it contains empirical facts from the phenomenon being studied.

\section{RESULT AND DISCUSSION}

The interview results and also the secondary research data analysis explained which general Natuna rural coastal already had development strategies generally contained based on the available development planning documents. The strategy existence that implemented in accordance with the implementation period is also quite relevant to the main development mission such as improving the citizen's welfare also the household economy conditions, improving the quality of the human resources of the community and the official rural government. the relevance between the development strategy and mission has not yet provided real development benefits that are felt by the community. Whereas development after therural autonomy era has been carried out over the repeated budget period. The community considers that the character of the rural area in the small island and separated from the main island requires a special and also comprehensive strategy. The research then confirms to information obtained externally that there are still perceived obstacles even though development activities have been carried out in rural coastal, for example in the effort to market the product " $\mathrm{X}$ " the work of the fishermen's wife broadly really requires considerable effort and funds.

A further alternatives description available in deciding the development strategy used, explains that as an organization that implements local selfgoverning, research has not found an alternative action choice where is contradictory to the main Natuna rural coastal developing mission. Even so, the citizens has not fully agreed with the adequate strategy. Some even think that there are development performance activities results are perceived to reduce the carrying environment capacity and contradict the traditional fishermen needs. This fact is confirmed by the 
existence of a physical development "Y" in the village which felt by fishing communities as a cause of the lack of certain species in the mangrove ecosystem.

There are research findings that pay enough attention, namely with regard to the results of the analysis that explain that overall development activities are programmed in the Natuna coastal villages, it still does not consider the risk of failure, especially in realizing development output that is beneficial for all levels of society in the village. These results were then confirmed and found a picture of the lack of representation of the people involved in formulating alternative strategies for building the Natuna rural coastal. This phenomenon then leads to the ignorance of the community towards the various outputs produced and feels that they have no initiative as outlined in the effort to rural development.

\section{CLOSING}

\section{Conclusion}

Based on the result anddiscussion, this research concludesabout the Natuna rural coastal development effectiveness process is influenced by the suitability of the strategy used. Inherently the research assesses that although the strategy used has relevance to the rural development main mission, in its realization requires activities alternative choices of in accordance with the needs and the community initiatives. The development process can concentrate again on the optimal involvement of rural coastal citizen and the communities.

\section{Recommendation}

Based on these conclusions, the research recommends several concrete actions that can be carried out by the rural official government, the citizen, and the business society in the village to increase the togetherness frequency through a well-known forum which can motivate a lot of parties presence including traditional fishermen. Using a Islamic religious approach according to this research is the most appropriate way to determine the more holistic format of rural citizens involvement. Togetherness and mutual cooperation should be the main principle of coastal village development located in the Republic of Indonesia border area.

\section{REFERENCE}

Bourgon, J. (2007) 'Responsive, responsible and respected government: Towards a New Public Administration theory', International Review of Administrative Sciences, 73(1), pp. 7-26. doi:

$10.1177 / 0020852307075686$.

Cameron, K. (1980) 'Critical Questions in Assessing Organizational Effectiveness', Organizaional Dynamics, pp. 66-80.

Coulter, P. B. (2015) 'EffecOrganizational tiveness in the Public Sector: The Example of Municipal Fire Protec- tion', 24(1), pp. 65-81.

Creswell W. John.(2013). Research

Design; Pendekatan Kualitatif, Kuantitatif, dan Mixed Method. Yogyakarta : Pustaka Pelajar.

Dehart-Davis, L. (2009) 'Green tape: A 
theory of effective organizational rules', Journal of Public Administration Research and Theory, 19(2), pp. 361-384. doi: 10.1093/jopart/mun004.

Goodsell, C. T. (2018) 'Leisha DeHartDavis, Creating Effective Rules in Public Sector Organizations', 00(expected), pp. 1-3. doi: 10.1111/puar.12944.

Herman, R. (1990) 'Methodological Issues an Studying the Effectivness of Nongovernmental and Nonprofit Organizations', Nonprofit and Voluntary Sector Quarterly, (19), pp. 293-306.

Herman, R. D. and Renz, D. O. (1999) 'Nonprofit and Voluntary Sector Quarterly Theses on Nonprofit Organizational Effectiveness', 28(2), pp. 107-126. doi: 10.1177/0899764099282001.

Herman, R. D. and Renz, D. O. (2004) 'Doing Things Right: Effectiveness in Local Nonprofit Organizations, A Panel Study', Public Administration Review, 64(6), pp. 694-704. doi: 10.1111/j.15406210.2004.00416.x.

Liket, K. C. and Maas, K. (2015) 'Nonprofit Organizational Effectiveness: Analysis of Best Practices', Nonprofit and Voluntary Sector Quarterly, 44(2), pp. 268296. doi: 10.1177/0899764013510064.

Nobbie, P. D. and Brudney, J. L. (2003) 'Testing the Implementation, Board Performance, and Organizational Effectiveness of the Policy Governance Model in Nonprofit Boards of Directors', Nonprofit and
Voluntary Sector Quarterly, 32(4), pp. 571-595. doi: 10.1177/0899764003257460.

Peraturan Pemerintah Republik Indonesia Nomor 43 Tahun 2014 (2014) Peraturan Pemerintah Republik Indonesia Nomor 43 Tahun 2014 Tentang Peraturan Pelaksanaan Undang-Undang Nomor 6 Tahun 2014 Tentang Desa.

Rainey, H. G. and Steinbauer, P. (1999) 'Galloping Elephants: Developing Elements of a Theory of Effective Government Organizations', 9, pp. 1-32.

Undang-undang Nomor 6 Tahun 2014 tentang Desa

Willems, J., Boenigk, S. and Jegers, M. (2014) 'Seven Trade-offs in Measuring Nonprofit Performance and Effectiveness', Voluntas, 25(6), pp. 1648-1670. doi: 10.1007/s11266-014-9446-1.

Wolf, P. J. (1993) 'A Case Survey of Bureaucratic Effectiveness in U.S - Cabinet Agencies: Preliminary Results 1', pp. 161-181. 